\title{
Construction and validation of an educational technology for mother-child bond in the neonatal intensive care unit
}

\author{
Construção e validação de tecnologia educacional para vínculo mãe-filho na unidade de terapia intensiva neonatal
} Construcción y validación de tecnología educativa para el enlace madre-niño en la unidad de cuidado intensivo neonatal



'Universidade Estadual do Ceará. Fortaleza, Ceará, Brazil. "Hospital Geral de Fortaleza. Fortaleza, Ceará, Brazil. "'Universidade Regional do Cariri. Crato, Ceará, Brazil.

How to cite this article: Santos AS, Rodrigues LN, Andrade KC, Santos MSN, Viana MCA, Chaves EMC. Construction and validation of an educational technology for mother-child bond in the neonatal intensive care unit. Rev Bras Enferm. 2020;73(4):e20190083. doi: http://dx.doi.org/10.1590/0034-7167-2019-0083

\section{Corresponding author: \\ Aliniana da Silva Santos \\ E-mail:enfa.aliniana@gmail.com

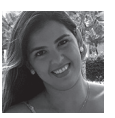

EDITOR IN CHIEF: Antonio José de Almeida Filho ASSOCIATE EDITOR: Hugo Fernandes

Submission: 03-21-2019

Approval: 06-09-2019

\section{ABSTRACT}

Objectives: to describe the process of construction and validation of an educational booklet to promote bonding between mothers and newborns in a Neonatal Intensive Care Unit. Methods: methodological study developed through data collection in the literature and with the target audience; construction of the booklet; qualification of the material through validation by judges (health and communication experts/designer) and assessment by the target audience (mothers of at-risk newborns). Data were analyzed descriptively. Results: booklet content was validated, obtaining an overall Content Validity Index of 0.92. Appearance was rated "Superior" with $80 \%$ percentage. Mothers performed an assessment with $100 \%$ agreement between the items. Conclusions: the booklet was validated in all domains assessed and can be used by mothers with children hospitalized in the Neonatal Unit.

Descriptors: Intensive Care Units, Neonatal; Educational Technology; Mother-Child Relations; Nursing; Validation Studies.

\section{RESUMO}

Objetivos: descrever o processo de construção e validação de uma cartilha educativa para promoção do vínculo entre mães e recém-nascidos em Unidade de Terapia Intensiva Neonatal. Métodos: estudo metodológico, desenvolvido mediante levantamento de dados na literatura e com o público-alvo; construção da cartilha; qualificação do material por meio de validação por juízes (especialistas das áreas da saúde e de comunicação/ designer) e avaliação pelo público-alvo (mães de recém-nascidos de risco). Os dados foram analisados de forma descritiva. Resultados: o conteúdo da cartilha foi validado, obtendo-se Índice de Validade de Conteúdo global de 0,92; a aparência foi qualificada como "Superior" com percentual de $80 \%$; e as mães realizaram avaliação com $100 \%$ de concordância entre os itens. Conclusões: a cartilha foi validada em todos os domínios avaliados, podendo ser utilizada por mães com filhos hospitalizados na Unidade Neonatal.

Descritores: Unidades de Terapia Intensiva Neonatal; Tecnologia Educacional; Relações Mãe-Filho, Enfermagem; Estudos de Validação.

\section{RESUMEN}

Objetivos: describir el proceso de construcción y validación de un folleto educativo para promover el vínculo entre madres y recién nacidos en una Unidad de Cuidados Intensivos Neonatales. Métodos: estudio metodológico, desarrollado a través de la recopilación de datos en la literatura y con el público objetivo; construcción del folleto; calificación del material mediante la validación por parte de jueces (especialistas/diseñadores de salud y comunicación) y evaluación por parte del público objetivo (madres de recién nacidos en riesgo). Los datos fueron analizados descriptivamente. Resultados: el contenido del folleto fue validado, obteniendo un índice de validez de contenido general de 0,92; la apariencia se clasificó como "Superior", con un $80 \%$ de porcentaje; y madres realizaron evaluación con $100 \%$ de acuerdo entre los ítems. Conclusiones: el folleto fue validado en todos los dominios evaluados y puede ser utilizado por madres con niños hospitalizados en la Unidad de Cuidado Intensivo Neonatal.

Descriptores: Unidades de Cuidado Intensivo Neonatal; Tecnología Educacional; Relaciones Madre-Hijo; Enfermería; Estudios de Validación. 


\section{INTRODUCTION}

At-risk newborn (NB) birth leads to early separation between mother and child, as the critical state of the baby requires specialized care in a Neonatal Intensive Care Unit (NICU). It is a complex environment full of invasive equipment and procedures, in which the NB is restricted to maternal care. This can interfere with motherchild relationship and make it difficult to establish a bond ${ }^{(1)}$. At NICU, interaction is a determining element for bonding. Mothers need support and help in adapting to this strange new environment, often experienced by them as negative, as well as encouragement to develop their maternal skills and build this bond with their baby ${ }^{(2)}$.

Nurses can combine technical care with the application of relational technologies to alleviate the negative effects of the environment on mothers. They can also encourage them, depending on the state of the baby, to participate in care such as bathing, changing diapers, touching and feeding by gavage and staying with their child most of the time, performing small daily tasks to strengthen the bond ${ }^{(3)}$.

Mothers should be guided by the nursing staff about care they can offer their children, in order to deconstruct the negative impression about the NICU environment and the difficulties of taking care of the baby, ensuring maternal protagonism and an adequate technique to promote the well-being of $\mathrm{NBs}^{(4)}$. When analyzing the mother's participation in care during the NB's hospitalization in a $\mathrm{NICU}$, it is pertinent to consider the theory of achieving the maternal role ${ }^{(5)}$. According to this theory, a woman recognizes herself as a mother only when she acquires competence to care for her child and expresses pleasure and satisfaction in playing this role ${ }^{(5)}$.

For this to happen, health education actions are needed with mothers of NBs admitted at NICU, in order to welcome them, reduce their doubts, alleviate negative feelings about hospitalization, enable and facilitate the performance of maternal care to the baby ${ }^{(4-6)}$.

Adequate training, especially of mothers during the hospitalization period, should be carried out in order to include them in NB care and provide support and dialogue among the professionals who assist them, in order to clarify them about the NICU environment ${ }^{(6)}$. At this moment, educational technologies emerge as important allies for the clarification of the NICU and also to prepare these mothers to provide adequate care for their children.

Of the various educational technologies currently available, we highlight printed materials, which are well accepted and used as an educational tool capable of broadening knowledge. Due to its easy applicability and reading, the educational booklet is one of the most used for audiences such as patients or families when the goal is to provide guidance ${ }^{(7)}$.

It is considered the lack of information from mothers about the NICU environment and the lack of maternal participation in basic care during the hospitalization of the child in the neonatal unit ${ }^{(2-}$ $4,6)$ as well as the importance of health professionals to promote mother-child interaction for bond formation. It is believed that the elaboration of an educational booklet for mothers of at-risk NBs can reduce the negative impact of the difficult experience of witnessing the child surrounded by equipment and encourage the performance of maternal care to promote bonding between bonding between mother and child hospitalized. It is emphasized that the construction of this bond is a primordial aspect for the development and growth of the baby.
Thus, the relevance of this research lies in the creation and validation of an educational booklet for NB mothers in NICU. It can be used in the first days of hospitalization of the baby, still in the welcoming phase, in order to reduce their initial impact and encourage the formation of bond between mother and child by performing daily care. It is emphasized that the booklet is based on the theory of achieving the maternal role ${ }^{(5)}$.

\section{OBJECTIVES}

To describe the process of constructing and validating an educational booklet to promote bonding between mothers and NB in NICU.

\section{METHODS}

\section{Ethical aspects}

All ethical aspects governing research involving human beings have been respected. The project was approved by the Research Ethics Committee of Hospital Geral de Fortaleza, under Opinion 2.710.388 and CAAE 90992918.0.0000.5040. Participation was voluntary and all mothers signed the Informed Consent Form. No conflict of interest is declared involved in this research.

\section{Design, place of study and period}

This is a methodological study, cut from the thesis under development entitled "Tecnologia educacional em enfermagem para a promoção do vínculo mãe-filho em unidade de terapia intensiva neonatal". The research followed the benchmark of quality improvement studies-SQUIRE of the EQUATOR network.

The educational booklet was built through steps suggested by Echer ${ }^{(8)}$, with adaptations: 1) submission of the qualified project to the Ethics and Research Committee; 2) literature survey and situational diagnosis with the target audience; 3 ) construction of the booklet, with drawings and layout made by a professional technical designer; 4) material qualification process through validation by judges (health experts and technical communication experts / designer) and assessment by the target audience.

An integrative literature review was conducted, guided by the following research question: "What health education actions are developed with parents of NBs hospitalized in NICU and their implications?". We analyzed 15 studies that showed different strategies of health education, such as focus groups, conversation circles, workshops, preparation and distribution of printed support materials (leaflets, information guides), lectures, videos, guidance from professionals to parents, use of informational site. The studies highlighted the mother as the main recipient of these interventions and the actions had the following implications: emotional support, participation in child care, improved interaction and knowledge regarding the NICU. It is worth mentioning the identification of only one Brazilian study and not having found a booklet that addressed the theme.

The situational diagnosis was made with 23 mothers of at-risk NBs in a public teaching hospital in the state of Ceará. They explained the need for learning about maternal care with the child and the lack of 
knowledge about the equipment used in the baby as factors that prevented them from performing this care. In addition, they reported feeling helpless because they did not know what care they could offer.

The booklet was entitled "Fios que ligam e desligam mãe efilho em Unidade de Terapia Intensiva Neonatal" (freely translated as Wires that connect and disconnect mother and child at the Neonatal Intensive Care Unit). The choice of neutral colors on the pages and images that symbolize the NICU environment aimed to visually organize the reading and make this material as close as possible to the reality of mothers who experience this moment of hospitalization.

In this excerpt, the material qualification process will be presented through content validation, appearance and assessment by the target audience, as well as the final version of the booklet. The content and appearance validation stage took place in September and October 2018. After suggestions and criticism from the judges, the final version of the booklet was assessed in November 2018 by mothers of risk NB.

\section{Population or study sample; inclusion and exclusion criteria}

Content validation was performed by health experts with experience in the field of neonatology, maternal and child or pediatrics. Already validation of appearance involved technical experts in the advertising field or designer, who assessed the booklet in terms of appearance, language and didactic aspects.

The sample was calculated by the formula: $\mathrm{n}=\mathrm{Za2}$. $\mathrm{P}$ (1-P)/e2, where " $Z$ " represents the confidence level, " $P$ " the expected proportion of experts, indicating the adequateness of each item, and " $\mathrm{e}$ " the acceptable proportional difference from what is expected ${ }^{(8)}$. A confidence level of $95 \%$ was considered, indicating that at least $70 \%$ of the experts would classify the item as adequate when using the values for the calculation: $Z a 2=1.96 ; P=0.85 ; e=0.15$. Thus, $a$ sample of at least 22 content and appearance experts was obtained ${ }^{(9)}$.

Given the need to establish parameters for the selection of content experts, we selected those who had at least five out of a total of fifteen criteria, namely: being a doctor; having a thesis in the area of interest; being a master; having a dissertation in the area of interest; having an article or work published in annals of scientific events in the area of interest; presenting clinical professional experience; teaching or research of at least one year in the area of interest; having at least one year of experience building and validating educational material in the area of interest; having expertise in the area of interest; have at least one year's experience in assessing educational tools or materials.

Technical experts were selected by at least three points out of ten according to the following criteria: minimum one-year experience in the area of interest (communication or designer), graduate in the area of interest, graduate degree and experience of at least one year in validation of educational tools or materials.

The assessment of the booklet was performed with the mothers of at-risk NBs in the NICU living space of a hospital belonging to the state neonatal reference network. Participants were selected by convenience according to the following inclusion criteria: mothers 18 years of age and older; regardless of gestational age; with a minimum of two days' hospitalization. It is noteworthy that this period is similar to another study conducted with mothers of at-risk NBs ${ }^{(4)}$ and is justified by the need for participants to assess whether the material produced was consistent with the reality they experienced when visiting their children.

It was also established that the participants had at least eight years of schooling, which was calculated by the degree of readability ${ }^{(10)}$ of the educational booklet produced. It is a calculation capable of identifying eventual learning limitations.

\section{Study protocol}

Eligible health experts were surveyed on the Lattes Platform of the Brazilian National Council for Scientific and Technological Development (CNPq - Conselho Nacional de Desenvolvimento Científico e Tecnológico) portal, using the following keywords: Pediatrics, Neonatology and Maternal and Child Health. Via email, 57 experts from different regions of Brazil were invited, of which 23 responded to the request.

Technical experts were chosen by intentional non-probability snowball sampling ${ }^{(11)}$. Thus, based on the list of the principal researcher, initial contact was made with professionals via e-mail to indicate other potential participants. Eight technical experts were contacted, of which six assessed the material.

After consent for the assessment of the educational material, the experts also received, by email, the SOP containing the necessary instructions and a form created by google docs with the Informed Consent Form (ICF), judge characterization. and tool assessment. The educational booklet was attached via google drive link.

Health experts assessed the booklet according to: 1) objectives; 2) structure and presentation; and 3) relevance ${ }^{(12)}$. The assessment of the booklet was made by Likert scale, according to the following assessment 1 = I Strongly Disagree; 2 = I Partially Agree; $3=$ I Neither Agree nor Disagree; 4 = I Agree; $5=$ I Strongly Agree.

Technical experts assessed the material using the Suitability Assessment of Material (SAM) tool ${ }^{(12)}$. This tool provides the opportunity to assess the product in the following areas: 1 ) Content, which refers to how the booklet is presented, including its general organization, structure, presentation strategy and sufficiency; 2) Language, understood as the level of reading of texts suitable for the comprehension of women with at least eight years of study; 3) Illustrations; 4) Layout and typography; 5) Motivation; and 6) Cultural adequacy ${ }^{(13)}$.

All experts were granted a 15-day return period. Those who did not return them within the pre-set period were offered an additional 15 days to return and those who did not respond within 30 days were excluded from the survey.

Assessment was performed with a target audience of ten mothers, quantitative described in the literature as the minimum of informants ${ }^{(14)}$. The researcher read the booklet individually with each mother and then allowed an average of five minutes to handle and read again. This application strategy is justified because in the next phase, called external validation, it will occur through an educational intervention, so that the initial reading of the booklet will be made by a nursing technician responsible for the reception, linked to the research hospital.

It was assessed whether the mothers understood the text and the illustrations. The assessment tool contained the following domains: 1) organization, 2) writing style, 3) appearance and 4) motivation of educational material; with positive, median or negative response options. 


\section{Data analysis}

For content validation, the Content Validity Index (CVI) score was calculated, which measures the proportion of content experts in agreement on certain aspects of the tool and its items. Allows you to analyze each item separately and then the tool as a whole. Sums of agreement of items scored 4 or 5 by health experts were used and Content Validity of Individual Items (I-CVI) divided by the number of health experts ${ }^{(15)}$. The formula used to calculate $\mathrm{CVI}=$ Number of answers 4 or 5 divided by the total number of answers ${ }^{(14)}$; considering a valid CVI greater than or equal to $0.90^{(16)}$.

It is noteworthy that when a considerable number of experts assess the material, there may be disagreement regarding the items ${ }^{(16)}$. If $\mathrm{I}-\mathrm{CVl}$ is below 0.90 , they can be assessed by at least three experts. However, for analysis of tools with three to five experts, the I-CVI is considered valid only when unanimous agreement of all items is obtained ${ }^{(17)}$.

SAM scores were assessed according to the classification: 2 points ="superior material", 1 point = "adequate material" and 0 point $=$ "inadequate material". The final score of the scores of each expert was transformed into percentage by summing the scores obtained, divided by the total scores and multiplied by 100 . Thus, the percentages of the scores achieved were analyzed as follows: when the booklet reaches the average score from $70 \%$ to $100 \%$, the educational material will be considered "Superior"; from 40 to $69 \%$, "Adequate"; and from 0 to $39 \%$, "Inadequate"(18).

After assessment by health experts and technical experts, a second version of the material was elaborated and submitted to a Portuguese revision. Then, the Flesch-Kincaid Readability (FKR) was calculated ${ }^{(10)}$, which assesses the readability of texts on a percentage scale from zero to one hundred. The texts were selected and assessed by the text analysis program available in Microsoft Office Word, version 2010. The FKR of each domain of the booklet was measured and judgments with FKR between $50-100 \%$ were considered acceptable. The $75-100 \%$ FKR is classified as "very easy", reaching reading school from the 4th grade; between 50 - 75\% is considered "easy", reaching an average of $8^{\text {th }}$ grade.

The second version of the booklet was assessed by the target audience, and items with a minimum agreement level of $75 \%$ in positive responses were validated ${ }^{(18)}$. The percentage of agreement was calculated based on the number of participants who agreed, divided by the total number of participants, multiplied by $100^{(14)}$.

Data were tabulated using Microsoft Excel version 2010 and analyzed using Brazil, 2018, N = 23 descriptive statistics. Expert suggestions have been incorporated into the final version of the booklet.

\section{RESULTS}

Twenty-nine judges participated in the validation: 23 health experts who assessed the booklet for content and six communication technicians/designer responsible for assessing appearance.

Most content experts were female (91.3\%), with a mean age of 38.8 years, with 29 being the minimum and 60 being the maximum. Regarding vocational training, $87 \%$ were nurses, $8 \%$ doctors and $4 \%$ psychologists. The average professional training time was 15 years: minimum of four and maximum of 36 years. Most were masters (52.2\%), $43.5 \%$ doctors and $21.7 \%$ experts in the field of interest. They worked professionally in the Northeast $(82.6 \%)$, South (8.6\%), Southwest (4.3\%) and North (4.3\%) Regions.

Table 1 - Educational booklet adequacy agreement assessment regarding CVI, Fortaleza, Ceará,

\begin{tabular}{|c|c|c|}
\hline Domains & Items Assessed & $\mathbf{I}-\mathbf{C V} \mathbf{I}^{*}$ \\
\hline \multirow[t]{7}{*}{ Objective } & $\begin{array}{l}\text { 1.1 The information/content presented in the booklet is consistent with } \\
\text { care and technologies that involve the NB in the NICU. }\end{array}$ & 1.0 \\
\hline & $\begin{array}{l}\text { 1.2 They suggest and/or instigate the mother's attitude towards the } \\
\text { performance of the maternal role from the basic care provided to the NB. }\end{array}$ & 0.91 \\
\hline & 1.3 They suggest promoting bonding between mother-baby. & 0.96 \\
\hline & 1.4 May assist in reducing maternal role tension in the NICU. & 0.96 \\
\hline & $\begin{array}{l}\text { 1.5 May assist in reducing maternal stress during hospitalization of the } \\
\text { child in the NICU. }\end{array}$ & 0.91 \\
\hline & 1.6 Can circulate in the scientific environment. & 0.96 \\
\hline & CVI & 0.96 \\
\hline \multirow[t]{12}{*}{$\begin{array}{l}\text { Structure/ } \\
\text { presentation }\end{array}$} & $\begin{array}{l}\text { 2.1 The booklet is suitable for the guidance of mothers about the NICU } \\
\text { environment, equipment, care provided by staff and mothers. }\end{array}$ & 0.96 \\
\hline & 2.2 The messages are presented clearly and objectively. & 0.74 \\
\hline & 2.3 The information presented is scientifically correct. & 0.83 \\
\hline & 2.4 Topics have logical sequence. & 0.96 \\
\hline & $\begin{array}{l}2.5 \text { The material is adequate to the socio-cultural level of the proposed } \\
\text { target audience. }\end{array}$ & 0.65 \\
\hline & $\begin{array}{l}\text { 2.6 The style of writing corresponds to the level of knowledge of the } \\
\text { target audience. }\end{array}$ & 0.70 \\
\hline & 2.7 The information is well structured in agreement and spelling. & 0.78 \\
\hline & 2.8 The illustrations are clear, easy to understand and sufficient. & 0.91 \\
\hline & $\begin{array}{l}\text { 2.9 The cover, back cover, presentation and final message information are } \\
\text { consistent. }\end{array}$ & 0.96 \\
\hline & 2.10 The number of pages is adequate. & 0.83 \\
\hline & 2.11 The font size of the title, topics, and body text is adequate. & 0.78 \\
\hline & $\mathrm{CVI}$ & 0.84 \\
\hline \multirow[t]{6}{*}{ Relevance } & $\begin{array}{l}\text { 3.1 Themes portray key aspects that should be reinforced regarding the } \\
\text { hospitalization of the baby in NICU }\end{array}$ & 0.96 \\
\hline & $\begin{array}{l}\text { 3.2 The booklet proposes the construction of knowledge and encourages the } \\
\text { mother to approach her child, promoting bonding between mother and child. }\end{array}$ & 1.0 \\
\hline & $\begin{array}{l}\text { 3.3 The developed items address important issues for the mother who } \\
\text { experiences her child's hospitalization in the NICU. }\end{array}$ & 0.96 \\
\hline & $\begin{array}{l}\text { 3.4 The booklet is suitable for use by any healthcare professional in their } \\
\text { educational activities with the target audience. }\end{array}$ & 1.0 \\
\hline & $\mathrm{CVI}$ & 0.98 \\
\hline & Overall CVI & 0.92 \\
\hline
\end{tabular}

Note: I-CVI - Content Validity of Individual Items; CVI - Content Validity Index. 
Table 2 - Educational booklet adequacy agreement assessment regarding CVI in the items related to the structure/presentation domain, Fortaleza, Ceará, Brazil, 2018, N =9

\begin{tabular}{lc}
\hline \multicolumn{1}{c}{ Reassessed Items of Structure/Presentation Domain } & I-CVI* \\
\hline 2.2 The messages are presented clearly and objectively. & 1.0 \\
2.3 The information presented is scientifically correct. & 1.0 \\
2.5 The material is adequate to the socio-cultural level of the proposed target audience. & 1.0 \\
2.6 Writing style corresponds to the level of knowledge of the target audience. & 1.0 \\
2.7 The information is well structured in agreement and spelling. & 1.0 \\
2.10 The number of pages is adequate. & 1.0 \\
2.11 The font size of the title, topics, and body text is adequate. & 1.0 \\
CVI & 1.0 \\
\hline Note: I-CVI-Content Validity of Individual Items; CVI-Content Validity Index. &
\end{tabular}

Table 3 - Educational booklet adequacy agreement assessment regarding the SAM score, Fortaleza, Ceará, Brazil, 2018, N = 06

\begin{tabular}{|c|c|c|}
\hline Domains & Items assessed & $\begin{array}{l}\text { Scores total/ } \\
\text { Scores } \\
\text { percentage (\%) }\end{array}$ \\
\hline \multirow[t]{3}{*}{ Content } & 1.1 The objective is evident. & $11(91,6)$ \\
\hline & $\begin{array}{l}\text { 1.2 The content addresses information related to NB in the NICU and } \\
\text { encourages the mother to participate in care. }\end{array}$ & $12(100)$ \\
\hline & 1.3 The purpose of the material is limited to the objectives. & $10(83.3)$ \\
\hline \multirow[t]{5}{*}{ Language } & 2.1 The reading level is adequate for mothers to understand. & $9(75)$ \\
\hline & 2.2 The language is clear and facilitates the understanding of the text. & $9(75)$ \\
\hline & 2.3 Uses common words. & $9(75)$ \\
\hline & 2.4 Uses active voice writing. & $11(91.6)$ \\
\hline & 2.5 There is a context in the booklet that comes before new information. & $9(75)$ \\
\hline \multirow{3}{*}{$\begin{array}{l}\text { Graphic } \\
\text { Illustrations }\end{array}$} & 3.1 The cover attracts attention and portrays the purpose of the material. & $10(83.3)$ \\
\hline & $\begin{array}{l}3.2 \text { Illustrations present fundamental visual messages so that the reader } \\
\text { can understand the main points without distractions; and uses adult- } \\
\text { adequate designs and strokes. }\end{array}$ & $10(83.3)$ \\
\hline & 3.3 Illustrations are adjacent to related text. & $10(83.3)$ \\
\hline \multirow[t]{9}{*}{$\begin{array}{l}\text { Layout and } \\
\text { typography }\end{array}$} & $\begin{array}{l}4.1 \text { Information layout and sequence are consistent, making it easy to } \\
\text { predict the flow of information. }\end{array}$ & $8(66.7)$ \\
\hline & 4.2 Visual devices are used to point to the main content. & $9(75)$ \\
\hline & 4.3 White space is used to reduce clutter. & $9(75)$ \\
\hline & 4.4 Uses compatible colors that are not far from the message. & $10(83.3)$ \\
\hline & 4.5 Text has upper and lower case letters. & $11(91.6)$ \\
\hline & 4.6 Font size is at least 12. & $8(66.7)$ \\
\hline & 4.7 There are typographic clues. & $7(58.3)$ \\
\hline & 4.8 Does not use long texts. & $7(58.3)$ \\
\hline & $\begin{array}{l}\text { 4.9 Titles and/or subtitles are used. Lists are grouped into descriptive } \\
\text { subheadings and no more than } 7 \text { items are presented without subtitles. }\end{array}$ & $10(83.3)$ \\
\hline \multirow[t]{3}{*}{ Motivation } & $\begin{array}{l}5.1 \text { Interaction of the text and/or pictures occurs with the reader, leading } \\
\text { the reader to understand the technologies surrounding the baby and } \\
\text { care, make choices and/or demonstrate skills in relation to maternal care. }\end{array}$ & $9(75)$ \\
\hline & 5.2 Desired behavior patterns are modeled or well demonstrated. & $10(83.3)$ \\
\hline & $\begin{array}{l}5.3 \text { Mothers are motivated to learn by believing that tasks and behaviors } \\
\text { are feasible. }\end{array}$ & $11(91.6)$ \\
\hline \multirow[t]{2}{*}{$\begin{array}{l}\text { Cultural } \\
\text { suitability }\end{array}$} & $\begin{array}{l}\text { 6.1 The material is culturally adequate to the logic, language and } \\
\text { experience of mothers who have children in NICU. }\end{array}$ & $10(83.3)$ \\
\hline & 6.2 Provides culturally adequate images and examples. & $11(91.6)$ \\
\hline \multicolumn{2}{|c|}{ Overall percentage of scores } & 80.0 \\
\hline
\end{tabular}

Note: SAM - Suitability Assessment of Material; NB - Newborn; NICU - Neonatal Intensive Care Unit.
The average time of experience in the areas related to the object under study was 11 years, with a minimum of two and a maximum of 30 years. $56.5 \%$ of content experts had experience with the construction and validation of printed educational material in the area of interest; $65.2 \%$ had already participated in an educational technology validation process and $100 \%$ had articles or papers published in annals of scientific events in the area of interest.

Most suggestions from health experts regarding the booklet's first version were answered: changing the cover image, reducing texts, enhancing images, using terms best known to mothers. It involved rewriting a few paragraphs for further understanding, adding two items about skin-to-skin contact and taking exams, and removing the text about the bath step by step.

The agreement between the judges regarding the educational material obtained an overall CVI of 0.92 in the first assessment, and its content was considered validated. Table 1 shows the individual and overall indices achieved in content validation by the 23 health experts.

Table 1 shows that seven items of the structure/presentation domain did not reach the recommended CVI and, therefore, were analyzed based on the final version of the booklet, which was sent to all 23 content experts, of which nine returned (Table 2 ).

Given the I-CVC and CVI of 1.0 in the re-assessment made by the experts of the latest version of the booklet, content validity is considered consolidated in all items.

Regarding validation of appearance, most $(66.7 \%)$ of the technical experts were male, with a mean age of 31 years: minimum 19 and maximum 52. Regarding the region of professional activity, $66.7 \%$ worked in the Northeast and $33.3 \%$ in the Southeast of Brazil. Regarding training, $66.7 \%$ were designers and $33.3 \%$ journalists. Most (66.7\%) had a broad sense of expertise in the field of designer or communication and $33.3 \%$ completed the master's degree. In addition, $83.3 \%$ had experience in the assessment of educational material, with an average of two years: minimum of one and maximum of five years. 
Table 4 - Educational booklet adequacy agreement assessment booklet by the target audience, Fortaleza, Ceará, Brazil, 2018

\begin{tabular}{|c|c|c|}
\hline Domains & Items assessed & Answers/ N (\%) \\
\hline \multirow[t]{3}{*}{ Organization } & 1.1 Did the cover catch your eye? & Yes/ $10(100)$ \\
\hline & 1.2 Is the content sequence adequate? & Yes/ $10(100)$ \\
\hline & 1.3 Is the structure of the educational booklet organized? & Yes/ $10(100)$ \\
\hline \multirow[t]{3}{*}{ Writting style } & 2.1 As for the understanding of the sentences, they are: & Easy to understand/ $10(100)$ \\
\hline & 2.2 Written content is: & Clear/10 (100) \\
\hline & 2.3 The text is: & Interesting/ $10(100)$ \\
\hline \multirow[t]{3}{*}{ Appearance } & 3.1 Are the illustrations simple? & Yes/ $10(100)$ \\
\hline & 3.2 Are illustrations meant to complement the text? & Yes/ $10(100)$ \\
\hline & 3.3 Do pages or sections appear organized? & Yes/ $10(100)$ \\
\hline \multirow[t]{4}{*}{ Motivation } & 4.1 Do you think any mother with a child in the neonatal ICU reading this booklet will understand what it is? & Yes/ $10(100)$ \\
\hline & 4.2 Did you feel motivated to read the booklet until the end? & Yes/ $10(100)$ \\
\hline & 4.3 Does the booklet address issues necessary for mothers who are having the same experience as you? & Yes/ $10(100)$ \\
\hline & 4.4 Did the booklet encourage you to care for your baby in the neonatal ICU? & Yes/ $10(100)$ \\
\hline \multicolumn{2}{|c|}{ Total Agreement Index Percentage } & $100 \%$ \\
\hline
\end{tabular}

Note: ICU - Intensive Care Unit.

Most of the suggestions were answered: soften the color of the cover (the first version had a darker shade of pink); change cover image (image of baby holding mother's finger has been replaced by image of mother holding baby on lap); align the texts; value the internal margin space; insert captions on images; reduce texts; insert the name of the topic covered only on the first page and on the others on the same theme use only the same color; harmonize the order and size of images and text. The texts of the first version were reduced and the images valued.

The items related to the assessment of the booklet appearance by the six technical experts obtained an overall percentage of $80 \%$, as detailed in Table 3.

After content validation and appearance, the booklet's final version was verified by the FKR and obtained a rate of $67 \%$, being classified as "easy to read", reaching $8^{\text {th }}$ grade average schooling.

Ten mothers of the target audience, with an average age of 31 years, 21 minimum and 42 maximum, participated in the assessment of the booklet. Regarding marital status, $80 \%$ reported stable / married union and $20 \%$ were single. Most (70\%) had completed elementary school II and 30\% had completed high school. Gestational age reached an average of 32 weeks: minimum 22 and maximum 39 weeks.

The average experience time at the time of hospitalization of children in the NICU was 45 days - minimum of three and maximum 126 days. The domains assessed by the mothers obtained a $100 \%$ agreement index, as shown in Table 4.

The mothers reported that the booklet was easy to understand, with a lot of information that could help clarify what happens in the NICU and care they can offer their baby. It is noteworthy that the majority $(60 \%)$ requested a copy of the booklet, which shows that it attracted the attention of the target audience, which was granted to all who requested it.

The booklet was formatted with a four-page number of a total of 24 A4 half-sheet $(150 \times 210 \mathrm{~mm})$ pages, set in landscape orientation. Five pages consist of pre-textual elements, fifteen on textual elements and four on post-textual elements. The material has four domains, each with a different color, and the printed version was made by a digital printing press, on bright-couche $110 \mathrm{~g}$ sheets, with $4 \times 4$ colors front and back. Figure 1 shows the cover and themes covered in the final version of the booklet.

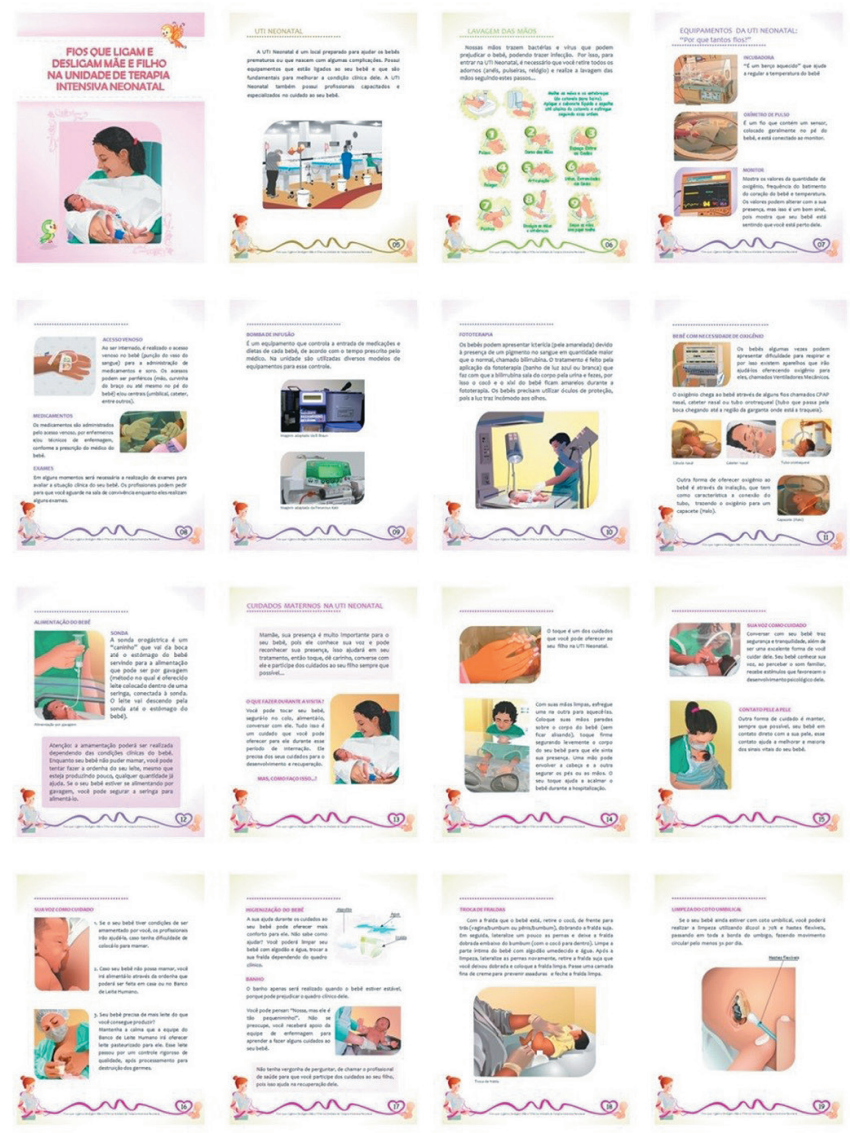

Figure 1 - Representation of the final version of the booklet entitled "Fios que ligam e desligam mãe e filho na Unidade de Terapia Intensiva Neonatal" (freely translated as Wires that connect and disconnect mother and child at the Neonatal Intensive Care Unit), Fortaleza, Ceará, Brasil, 2018 


\section{DISCUSSION}

The internal validity of the new educational material produced was obtained. The assessment of health experts presented content validity with global CVI of $0.92^{(16)}$, considering the booklet validated. The index adopted in this research is higher than the minimum value used and there was also the inclusion of a larger number of experts in comparison with other validation studies ${ }^{(19-22)}$. Nurses, doctors and psychologists participated in this process, which expresses recognition of the relevance of promoting the diversity of opinions and approaches on the same theme to ensure greater tool reliability ${ }^{(19)}$.

The changes made in the booklet's first version allowed a better understanding of the language, as observed in another research that elaborated a booklet for the reception of "kangaroo family" in a neonatal unit. This study highlighted the importance of detachment from the booklet's first version for language, culture and knowledge adequacy of the target audience ${ }^{(20)}$.

Regarding appearance, the technical experts scored the booklet with a mean score of $80 \%$, being rated higher than the set of items assessed. Classification was similar to other appearance validation studies of educational booklets using SAM ${ }^{(22-23)}$.

Modified booklet items presented in their latest version resulted in an FKR of $65 \%$. It was considered an easy reading, converging with the assessment of mothers who presented $100 \%$ agreement index in all items assessed, and a CVI of 1.0 in the second round among content experts. These data show the gains in readability and comprehension about the latest version of the booklet produced and validated. Audience assessment is important in identifying whether material actually portrays the reality of the intended people, as well as whether they become more willing to adopt new behaviors when they identify proximity to their reality ${ }^{(21)}$.

In this aspect, the images of the booklet were praised by all the judges and also by the mothers, due to the approximation of the drawings with reality. It was considered adequate to mediate the reception and encourage maternal participation in baby care during the first days of hospitalization of the child in the NICU and able to facilitate interaction to promote bonding between mother and child.

The content addressed by the booklet about the NICU environment, the equipment and care that mothers can offer their children during hospitalization is reported in the national and international literature as a source of welcome and incentive to promote mother and child interaction. It is a tool capable of promoting bonding between them and can reduce stress during hospitalization ${ }^{(20,24-26)}$, which reinforces the importance of its use.

A printed educational technology called "Baby Diary", brought by a qualitative descriptive study, was delivered to mothers containing information about equipment and devices, pathologies of prematurity, breastfeeding, care for discharge, vaccines, space for notes and record of feelings. The authors observed that the technology aroused feelings of bond and affection, but did not undergo validation for measures of effect ${ }^{(24)}$.

Another educational intervention taught mothers how to engage in care such as diaper changing, bathing and feeding through interactions and stimulating confidence to perform such care, improving the interaction between mother and child ${ }^{(27)}$. In another study, an information guide for NICU parents on baby safety, diet, medical care, equipment types and importance of post-discharge follow-up, containing color photos of the NICU, involved emotional support and increased parental knowledge ${ }^{(23)}$.

Therefore, it is noticed that health education actions mediated by printed educational technology represent an innovative action in the NICU, especially when related to caring-educating for the welcoming of relatives of hospitalized NBs ${ }^{(20)}$. Another educational intervention research that also used printed material, but in the form of leaflets, instructed mothers about touch, eye contact, conversation with the baby and the kangaroo method, with the effect of greater interaction between mother and child ${ }^{(26)}$.

Thus, the educational technology presented here may bring positive results in relation to the bond, by encouraging mothers to always be close to the baby and to perform daily care. The new educational booklet can be considered a valid, reliable, attractive and innovative educational technology in actions aimed at the reception and encouragement of mothers in baby care in NICU. It may favor the formation of bond between mother and child, and should be tested for their effects.

\section{Study limitations}

Due to the significant amount of information presented in the booklet, the complexity of the NICU environment and the division of topics on hard technologies and maternal care, it was difficult to reduce texts and page numbers, which can make reading tiresome. However, to alleviate this limitation, the booklet should first be read by a healthcare professional and then delivered to the mother for use whenever she wishes.

\section{Contributions to Nursing, Health or Public Policy}

This booklet can be used both to support mothers in child care within the NICU and in nursing care. Its viability in the NICU is considered, because its content is based on the literature and the needs highlighted by the mothers who experience this moment. It may influence the change of practice by nursing, by raising awareness about the need for the mother's reception and insertion in basic care, currently under the responsibility of the nursing staff. The booklet is innovative because it is the first produced on the theme based on the theory of achieving the maternal role and validated by experts from different regions of Brazil, and may contribute to the humanization of care and best practices in neonatology.

\section{CONCLUSIONS}

The experts considered the booklet to be adequate as to the items referring to the objectives, structure, presentation and relevance, thus being considered adequate within the scientific rigor of validity. The level of understanding by the target audience was reached and can be used by mothers who experience their child's hospitalization period in NICU.

The material produced can function as an important embracing tool in the NICU and can be used in any Brazilian neonatal unit. It aims to arouse in mothers the willingness to take responsibility for 
the basic care of their child. Nevertheless, the use of the booklet should be accompanied by awareness of health professionals to encourage maternal leadership in NICU. This booklet is expected to be a technology incorporated into NICUs to promote bonding between mother and child during hospitalization.

\section{FUNDING}

This study had financial support from Coordination for the Improvement of Higher Education Personnel (CAPES - Coordenação de Aperfeiçoamento de Pessoal de Nível Superior).

\section{REFERENCES}

1. Pontes GAR, Cantillino A. [The influence of premature birth in mother-baby relationship]. J Bras Psiquiatr. 2014;63(4):290-8. doi: 10.1590/00472085000000037 Portuguese.

2. Medina IMF, Granero-Molina J, Ernández-Sola C, Hernández-Padilla JM, Ávila MC, Rodríguez MML. Bonding in neonatal intensive care units: experiences of extremely preterm infants' mothers. Women Birth. 2018;31(4):325-30. doi: 10.1016/j.wombi.2017.11.008

3. Nieto GCS, Rugolo LM, Sadeck LSR, Silveira RC, Garbers R. Nascer prematuro: Manual de orientação aos pais, familiares e cuidadores de prematuros na alta hospitalar [Internet]. Rio de Janeiro: Elsevier; 2016 [cited 2018 Dec 02]. Available from: http://www.spsp.org.br/PDF/ Manual\%20de\%20orientacao\%20pais\%20de\%20prematuros.pdf.

4. Veronez M, Borghesan NAB, Corrêa DAM, Higarashi IH. Experience of mothers of premature babies from birth to discharge: notes of field journals. Rev Gaúcha Enferm. 2017;38(2):e60911. doi: 10.1590/1983-1447.2017.02.60911

5. Mercer RT. Becoming a Mother Versus Maternal Role Attainment. J Nurs Scholarship. 2004;36(3):226-32. doi: 10.1111/j.1547-5069.2004.04042.x

6. Couto CS, Tupinambá MC, Rangel AUM, Frota MA, Martins EMCS, Nobre CS, Landim FLP. Spectra of mothers of premature children about the educative circle of culture. Rev Esc Enferm USP. 2014;48(Esp2):03-08. doi: 10.1590/S0080-623420140000800002

7. Oliveira SC, Lopes MVO, Fernandes AFC. Development and validation of an educational booklet for healthy eating during pregnancy. Rev Latino-Am Enfermagem. 2014;22(4):611-20. doi: 10.1590/0104-1169.3313.2459

8. Echer IC. [The development of handbooks of health care guidelines]. Rev Latino-Am Enfermagem. 2005;13(5):754-7. doi: 10.1590/S010411692005000500022 Portuguese.

9. Arango HG. Bioestatística teórica e computacional. 3 ed. Rio de Janeiro: Guanabara Koogan, 2009. 460 p.

10. Teles LM, Oliveira AS, Campos FC, Lima TM, Costa CC, Gomes LF, et al. Development and validating an educational booklet for childbirth companions. Rev Esc Enferm USP. 2014;48(6):977-84. doi: 10.1590/S0080-623420140000700003

11. Vinuto J. A amostragem em bola de neve na pesquisa qualitativa: um debate em aberto. Temáticas. 2014;22(44):203-20. Available from: https://www.ifch.unicamp.br/ojs/index.php/tematicas/article/view/2144/1637

12. Mota FRN, Victor JF, Silva MJ, Bessa MEP, Amorim VL, Cavalcante ML et al. Cross-cultural adaptation of the Caregiver Reaction Assessment for use in Brazil with informal caregivers of the elderly. Rev Esc Enferm USP. 2015;49(3):426-34. doi: 10.1590/S0080-623420150000300010

13. Sousa CS, Turrini RNT, Poveda VB. Translation and adaptation of the instrument "suitability assessment of materials" (SAM) into Portuguese. Rev Enferm UFPE. 2015;9(5):7854-61. Available from: https://periodicos.ufpe.br/revistas/revistaenfermagem/article/view/10534/11435

14. Atran S, Medin DL, Ross NO. The cultural mind: environmental decision making and cultural modeling within and across populations. Psychol Review. 2005;112(4):744-76. doi: 10.1037/0033-295X.112.4.744

15. Alexandre NMC, Coluci MZO. Validade de conteúdo nos processos de construção e adaptação de instrumentos de medidas. Ciênc Saúde Coletiva. 2011;16(7):3061-8. doi: 10.1590/S1413-81232011000800006

16. Polit DF, Beck CT, Hungler BP. Fundamentos de pesquisa em enfermagem: avaliação de evidências para a prática da enfermagem. 9 ed. Porto Alegre (RS): Artmed, 2019. 431 p.

17. Polit DF, Beck CT, Owen SV. Focus on Research Methods Is the CVI an Acceptable Indicator of Content Validity? appraisal and Recommendations. Res Nurs Health. 2007;30:459-67. doi: 10.1002/nur.20199

18. Martins MC, Veras JE, Uchoa JL, Pinheiro PN, Vieira NF, Ximenes LB. Food safety and the use of regional foods: the validation of a serial album. Rev Esc Enferm USP. 2012;46(6):1355-62. doi: 10.1590/S0080-62342012000600011

19. Lima AC, Bezerra KC, Sousa DM, Rocha JF, Oriá MO. Development and validation of a booklet for prevention of vertical HIV transmission. Acta Paul Enferm. 2017;30(2):181-9. doi: 10.1590/1982-0194201700028

20. Nascimento MHM, Teixeira E. Educational technology to mediate care of the "kangaroo family" in the neonatal unit. Rev Bras Enferm. 2018;71(suppl 3):1290-7 doi: 10.1590/0034-7167-2017-0156

21. Lima MA de, Pagliuca LM, Nascimento JC, Caetano JA. Virtual guide on ocular self-examination to support the self-care practice for people with hiv/aids. Rev Esc Enferm USP. 2014;48(2):285-91. doi: 10.1590/S0080-6234201400002000013

22. Moura IH, Silva AFR, Rocha AESH, Lima LHO, Moreira TMM, Silva ARV. Construction and validation of educational materials for the prevention of metabolic syndrome in adolescents. Rev Latino-Am Enfermagem. 2017;25:e2934. doi: 10.1590/1518-8345.2024.2934

23. Sabino LM, Ferreira AM, Joventino ES, Lima FE, Penha JC, Lima KF, et al. Elaboration and validation of a reader on childhood diarrhea prevention. Acta Paul Enferm. 2018;31(3):233-9. doi: 10.1590/1982-0194201800034 
24. Leite CCP, Souza SNDH, Rossetto EG, Pegoraro LGO, Jacinto VCB. The Baby's Diary to the premature infant's mother: supporting familycentered care. Rev Enferm UERJ. 2016;24(1):e8664. doi: 10.12957/reuerj.2016.8664

25. Friedman J, Friedman SH, Collin M, Martin RJ. Staff perceptions of challenging parent-staff interactions and beneficial strategies in the Neonatal Intensive Care Unit. Acta Paediatrica. 2018;107(1):33-39. doi: 10.1111/apa.14025

26. Silva IO, Aredes ND, Bicalho MB, Delácio NC, Mazzo LD, Fonseca LM. Booklet on premature infants as educational technology for the family: quasi-experimental study. Acta Paul Enferm. 2018;31(4):334-41. doi: 10.1590/1982-0194201800048

27. Benzies KM, Shah V, Aziz K, Isaranuwatchai W, Palacio-Derflingher L, Scotland J et al. Family Integrated Care (FICare) in Level II Neonatal Intensive Care Units: study protocol for a cluster randomized controlled trial. Infant Behav Dev. 2017;37(4): 695-710. doi: 10.1186/s13063-017-2181-3 